\title{
The relationship between career competencies, career identity, motivation and quality of choice
}

Citation for published version (APA):

Meijers, F., Kuijpers, M., \& Gundy, C. (2013). The relationship between career competencies, career identity, motivation and quality of choice. International Journal for Educational and Vocational Guidance, 13(1), 47-66. https://doi.org/10.1007/s10775-012-9237-4

DOI:

10.1007/s10775-012-9237-4

Document status and date:

Published: 20/01/2013

Document Version:

Peer reviewed version

Document license:

CC BY-SA

Please check the document version of this publication:

- A submitted manuscript is the version of the article upon submission and before peer-review. There can be important differences between the submitted version and the official published version of record. People interested in the research are advised to contact the author for the final version of the publication, or visit the DOI to the publisher's website.

- The final author version and the galley proof are versions of the publication after peer review.

- The final published version features the final layout of the paper including the volume, issue and page numbers.

Link to publication

\section{General rights}

Copyright and moral rights for the publications made accessible in the public portal are retained by the authors and/or other copyright owners and it is a condition of accessing publications that users recognise and abide by the legal requirements associated with these rights.

- Users may download and print one copy of any publication from the public portal for the purpose of private study or research.

- You may not further distribute the material or use it for any profit-making activity or commercial gain

- You may freely distribute the URL identifying the publication in the public portal.

If the publication is distributed under the terms of Article 25fa of the Dutch Copyright Act, indicated by the "Taverne" license above, please follow below link for the End User Agreement:

https://www.ou.nl/taverne-agreement

Take down policy

If you believe that this document breaches copyright please contact us at:

pure-support@ou.nl

providing details and we will investigate your claim.

Downloaded from https://research.ou.nl/ on date: 26 Apr. 2023 
The relationship between career competencies, career identity, motivation and quality of choice

\section{Frans Meijers, Marinka Kuijpers \& Chad Gundy}

International Journal for Educational and Vocational Guidance

ISSN 0251-2513

Int J Educ Vocat Guidance

DOI 10.1007/s10775-012-9237-4

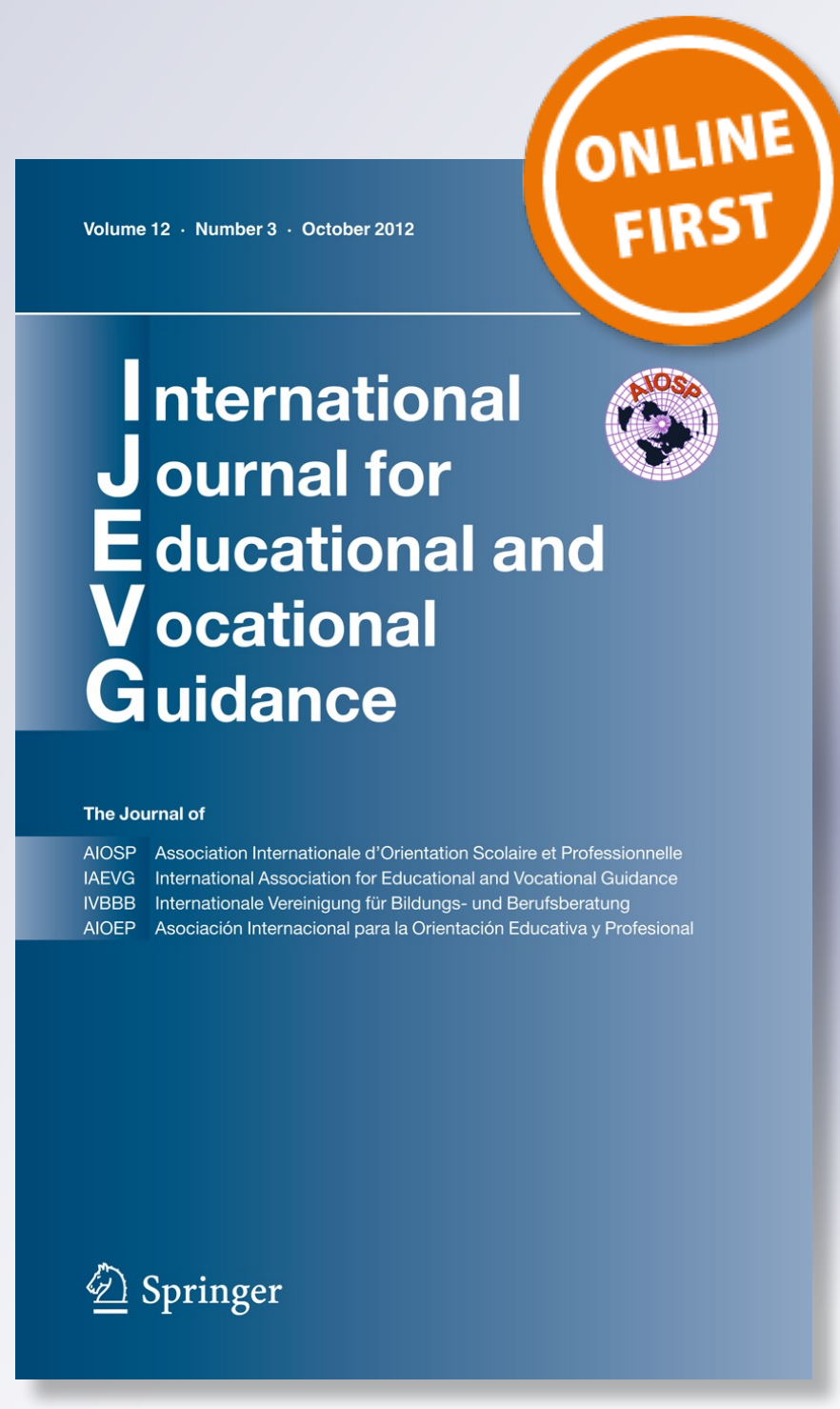

黛 Springer 
Your article is protected by copyright and all rights are held exclusively by Springer Science +Business Media Dordrecht. This e-offprint is for personal use only and shall not be selfarchived in electronic repositories. If you wish to self-archive your work, please use the accepted author's version for posting to your own website or your institution's repository. You may further deposit the accepted author's version on a funder's repository at a funder's request, provided it is not made publicly available until 12 months after publication. 


\title{
The relationship between career competencies, career identity, motivation and quality of choice
}

\author{
Frans Meijers • Marinka Kuijpers • Chad Gundy
}

Received: 15 January 2011/ Accepted: 24 December 2012

(C) Springer Science+Business Media Dordrecht 2013

\begin{abstract}
In this article we focus on the effects of career education and guidance among students (ages 12-19) enrolled in prevocational and secondary vocational education in The Netherlands. Our study included 3,499 students and 166 teachers in 226 classes in 34 schools. The results showed that career competencies positively contributed to learning motivation, experienced quality of study choice, experienced fit of choice with learning tasks, and experienced fit of internship. Career identity positively contributed to career outcomes, and career dialogue contributed more than traditional interventions have with respect to career outcomes.
\end{abstract}

Résumé. La relation entre les compétences professionnelles, l'identité professionnelle, la motivation et la qualité des choix. Dans cet article, nous nous concentrons sur les effets de l'éducation en orientation et du conseil en orientation professionnelle sur des étudiants (âgés de 12 à 19 ans) inscrits en formation préprofessionnelle et professionnelle aux Pays-Bas. Notre étude a porté sur 3499 élèves et 166 enseignants dans 226 classes et 34 écoles. Les résultats montrent que les compétences professionnelles contribuent positivement à la motivation à l'apprentissage, la qualité de l'expérience du choix d'études, la qualité vécue de l'ajustement du choix aux tâches d'apprentissage et l'ajustement vécu à la pratique. L'identité professionnelle contribue positivement aux résultats en lien avec la carrière, et le dialogue de carrière contribue plus aux résultats en lien avec la carrière que ne le font les interventions traditionnelles.

Zusammenfassung. Die Beziehungzwischen Karriere Kompetenzen, beruflicher Identität, Motivation und Qualität der Wahl. In diesem Artikel konzentrieren wir uns auf die Auswirkungen der Berufsorientierung und Beratung unter Schülern (Alter

F. Meijers $(\bowtie) \cdot$ M. Kuijpers · C. Gundy

Lectoraat Pedagogiek van de Beroepsvorming, The Hague University, P.O. 19320,

$2500 \mathrm{CH}$ Den Haag, The Netherlands

e-mail: fj.meijers@xmsnet.nl 
12-19) eingeschrieben in berufsvorbereitenden und berufsbildenden weiterführenden Schulen in den Niederlanden. Unsere Studie umfasste 166 Lehrer und 3499 Schüler in 226 Klassen in 34 Schulen. Die Ergebnisse zeigten, dass Karriere Kompetenzen einen positiven Beitrag leisteten zur Lernmotivation, der Qualität der Studienwahl, der empfundenen Passung der Wahl mit Lernaufgaben und der empfundenen Passung des Praktikums. Karriere Identität hatte positive Karriere-Effekte und Gespräche über Karriere trugen im Hinblick auf Effekte mehr bei als traditionelle Interventionen.

\section{Resumen. La relación entre las competencias profesionales, la identidad profesional, la motivación y la calidad de la elección. En este artículo nos centramos en los efectos de la educación y orientación profesional de los estudiantes (entre 12 y 19 años) matriculados en preorientación y educación profesional en secundaria en los Países Bajos. Nuestro estudio incluyó a 3499 estudiantes y 166 profesores en 226 clases de 34 escuelas. Los resultados mostraron que las compe- tencias profesionales contribuyen positivamente a la motivación por aprender, la calidad de la experiencia del estudio elegido, experimentaron el ajuste de la elección con las tareas de aprendizaje y las prácticas. La identidad profesional contribuyó positivamente a los resultados de la trayectoria profesional, y el diálogo de esta trayectoria contribuyó más que las intervenciones tradicionales con respecto a los resultados de la carrera profesional.}

\section{Keywords Career guidance $\cdot$ Outcome effects - Vocational education}

Since the 1980s, the range of possible occupational and educational choices has increased dramatically in Western societies (Organisation for Economic Cooperation and Development [OECD], 2004). As a result, individuals are faced with a growing pressure to make choices, while at the same time, and due to flexibilisation of employment relationships (Arthur, Inkson, \& Pringle, 1999) and individualisation within society (Beck, 1994), less and less direction is provided (demonstrated, for example, by the unpredictability of careers; cf. Arthur, Khapova, \& Wilderom, 2005). The individual is expected to demonstrate more self-directedness both on the labour market (Kuijpers \& Scheerens, 2006; Savickas, 2000) and in society as a whole (Giddens, 1991). In addition, the personalities of employees in a service economy are becoming an increasingly important production factor (Hochschild, 1983; Sennett, 1998).

As a result of the shifting economy and changing notions of work (Krumboltz \& Worthington, 1999; Savickas, 2000; Savickas, Van Esbroeck, \& Herr, 2005) schools are increasingly acknowledging that they have a strong responsibility to guide students not only in their academic growth, but also in their career development (Gysbers \& Henderson, 2005; Jarvis \& Keeley, 2003; Mittendorff, 2010). Although in Western societies employers expect new employees to have more knowledge, more skills and-moreover-that they will be more intrinsically motivated than three decades ago (Bailey, Hughes, \& Moore, 2004), Dutch vocational education does not fulfil these promises. There are serious doubts about the level of knowledge and skills students have. Several studies seem to indicate that a majority of students 
are not intrinsically motivated when they enter school (Holt, 1995; Light, 2001; Prawat, 1998; Tinto, 1993, 2000; Zijlstra \& Meijers, 2006). Moreover, the majority of Dutch students is - at least in the first 2 years of their study-uncertain about their career choice, leading to a high drop-out rate (Dieleman \& Meijers, 2005). Most students fail to develop a clear career wish during their time in school, leading to rather random educational choices and a subsequent 30 to $50 \%$ drop-out rate (Eurostat, 2008; National Center for Education Statistics, 2001).

Policy makers as well as school managers believe that intensive career education and guidance will reduce dropout rates (Company, 2009). In 2001, a committee installed by the Dutch Minister of Education stated that intensive career education and guidance will result in more intrinsically motivated students because it will help students develop a career identity (Geurts \& Meijers, 2009). A career identity is defined as the commitment a person has towards specific occupational activities or a specific career (Wijers \& Meijers, 1996). A well-developed career identity will result, the committee argued, in less dropout, better or more stable educational choices and "qualification gains" (i.e. an increase in students who successfully complete secondary or tertiary vocational education). However, as yet, there is little evidence that these proposed investments in careers education and guidance will truly result in more commitment towards work and therefore in less dropout, better choices, and qualification gains.

\section{The effects of education-based career development}

In Western nations, career guidance in education is still primarily based on the traitand-factor approach (Irving \& Malik, 2005; Watts \& Sultana, 2004). In this approach, focus is placed on achieving the best possible match between the skills of an individual and the "right" education, training or job opportunities. Many scholars, however, have argued that there is little research supporting the trait-andfactor approach as a viable way of fostering career development; especially its usefulness in fluid labour market conditions has been questioned, since matching assumes a degree of stability (Krumboltz \& Worthington, 1999). Career paths have become unpredictable; therefore, it is no longer possible to make career choices in a purely rational and information-based way (Guindon \& Hanna, 2002; Krieshok, Black, \& McKay, 2009; Mitchell, Levin, \& Krumboltz, 1999). However, despite these shortcomings, the model is dominant in effect studies. Indeed, the trait-andfactor model offers clear constructs that are relatively easy to measure. It is assumed that students can match their skills with education, training or job opportunities efficiently, if they have enough information about (a) their own skills, preferences and personality and (b) the educational, training or job requirements. Almost all effect studies concentrate on this relationship; only a few researchers concentrate on the process of guidance (Bimrose, Barnes, Hughes, \& Orton, 2004).

When it comes to career guidance, research shows that the focus is mainly on helping students with their academic achievement and not on helping students plan and prepare for their work roles afterwards (Meijers, 2008; Parsad, Alexander, 
Farris, \& Hudson, 2003). There is evidence, however scattered, that career guidance and education affects a number of outcome measures, especially with regard to decision-making skills and knowledge of work and occupations. Meta-analyses by Oliver and Spokane (1988), and Whiston, Sexton and Lasoff (1998) showed that career interventions that try to help students plan and prepare for their work roles, have the most impact on the development of career decision-making skills, as compared to other possible skills, such as career-related knowledge or career-related self-concept development. These results showed that students who took a careerdecision making course demonstrated less career-related indecision at the end of the course than did a comparison group (McWhirter, Rasheed, \& Crothers, 2000). For example Killeen, Edwards, Barnes, and Watts (1999) showed that participation in The Real Game - a game that forces participants to make career decisions-results in an increase in knowledge of work and occupations. Knowing how the world of work is organized eases the process of vocational decision making and job transition. Especially important is the acquisition of a "compact view of the world of work at a more manageable level of abstraction" (Dawis, 1996, p. 239). Career interventions that help individuals to gain self-knowledge about where they can be satisfactory and satisfied workers, also ease occupational choice making and enhance work adjustment (Savickas 2002). Effective guidance has "immediate outcomes," especially enhanced knowledge and skills, including the ability to create effective transitions, change attitudes including building self-confidence and esteem, which increases motivation and the willingness to consider new employment or learning options (Hughes, Bosley, Bowes, \& Bysshe, 2002; Killeen, 1996; Killeen, White, \& Watts, 1992).

\section{Research question}

Most literature about vocational guidance effectiveness is focused on change in students' knowledge, attitudes and decision-making skills, while students' behaviors usually are not examined. Hughes and Karp (2004) claimed that research should focus on exploring the relationships between guidance interventions and positive students' behavioral outcomes. This study did not analyze the influence of schoolbased career interventions on decision-making skills, attitudes or knowledge but on actual career behavior, i.e. career competencies of students. Career competencies, according to Kuijpers and Scheerens (2006), include: making concrete the thinking about one's own motivation and aptitudes (career reflection), giving shape to one's own career path by exploring the options in study and work (career exploration), truly steering one's own learning process (career action), and building and maintaining a network (networking). Moreover, a learning environment that stimulates real-life experiences with work and a dialogue about these experiences does contribute to the use of career competencies (Kuijpers, Meijers \& Gundy, 2011). In particular, the career dialogue with teachers and the conversation students have in the workplace with professionals has proven to be crucial. An explanation for the important role of dialogue in the development of career competencies is offered by constructivist learning theory, which states that meaning is constructed 
when individuals engage in a dialogue with oneself and others (Bruner, 1990). The theory of career construction (Savickas, 2002, 2005) is the most developed constructivist approach with respect to career learning. Savickas stated that career construction, at any given stage, can be fostered by conversations. In his theory, three areas are emphasized: vocational personality, career adaptability, and life themes. Savickas advanced the idea of life themes at the level of personal narrative and subjective career; he positioned life stories in a way that show they are the crucial threads of continuity that make meaningful the elements of vocational personality and career adaptability. Career-related stories express the uniqueness of an individual and explain why he or she makes choices and explicates the meanings that guide those choices. Career stories "tell how the self of yesterday became the self of today and will become the self of tomorrow" (Savickas, 2005, p. 58).

The aim of this study was to investigate the relationship between career competencies and career identity, learning motivation, and the quality of career choices. Firstly, we wanted to examine the relationship between career competencies and career identity and the role of the career learning environment with respect to this relationship. A positive correlation was expected between career competencies and career identity (Kuijpers et al., 2011). Secondly, we examined the relationship between career competencies and career identity on the one hand and four criterion variables on the other: (1) learning motivation, and (2) experienced quality of choice for a study, (3) for learning tasks, and (4) for work placements. We investigated whether career competencies and career identity were mediating variables, but we also examined whether there was a direct relationship between career competencies and career identity and the criterion variables. We expected a positive correlation because career competencies and a career identity provide the student with a feeling of direction (Wijers \& Meijers, 1996), not only in a cognitive but also in an emotional sense (Krieshok et al., 2009). Because emotions drive attention (Frijda, 1989), which in turn drives learning (Van Woerkom, 2008), career competencies and especially a career identity probably have a positive effect on learning motivation and the experienced quality of choice. We did not examine, however, the role of emotions.

\section{Method}

\section{Participants}

The sample was drawn via a multi-stage process. In the first stage, all 342 prevocational educational (PVE) and all 18 secondary vocational educational (SVE) schools in The Netherlands were invited to a conference concerning career guidance and counseling in Fall 2006. As in the US, in The Netherlands vocational education is synonymous with "technical education" and usually refers to trade schools that teach manual or practical activities, traditionally non-academic. ${ }^{1}$ The organization

\footnotetext{
1 The Dutch educational system has two main tracks after primary education. Almost $60 \%$ of all students enter the vocational track, starting with pre-vocational education (ages 12-16), followed by
} 
of the conference was subsidized by the Department of Education. Representatives of the attending schools were approached by the researchers and asked whether they would like to participate in the present study. Of those attending, 18 of the PVEs (23\%), and 17 of the SVE's (94\%) responded positively. Each school that responded affirmatively then selected teachers and their students, and they were asked to participate. School managers made the decision as to which classes would participate in this study. No information is available concerning how the managers made these selections.

Participating schools were spread throughout The Netherlands, and included inner-city schools as well as those in rural regions. There were no significant differences between participating schools and non-participating schools with respect to size, school population (especially with respect to gender and ethnicity), and environment (urban vs. rural). A total of 3,499 students from 198 classes in the 35 schools participated in the study.

Slightly more than half of the responding students were male, and approximately $10 \%$ considered themselves to be members of a minority group. Their average age was 18 years, though this variable is skewed as a number of the students were older than 40 years. Almost one-third of the students specialized in health care, and almost two-thirds attended secondary vocational education (SVE). Approximately $50 \%$ of the students stated that they had an assigned counsellor in their schools; the others did not know (all schools do have counselors, but in many schools this becomes visible for students only when they have problems).

\section{Instruments}

\section{Career competencies}

Career competences were assessed using an adapted questionnaire developed for the needs of this study. This instrument was inspired by the questionnaire developed by Kuijpers and Scheerens (2006) and Kuijpers, Schyns, and Scheerens (2006) for measuring competences among employees. In the adapted questionnaire three competences are set out: career-reflection (characterized by reflective behavior), career-forming (characterized by pro-active behavior), and networking (characterized by interactive behavior). The response categories of the items vary

\footnotetext{
Footnote 1 continued

secondary vocational education (ages 16-20). In secondary vocational education, students can choose 2-, 3- or 4-year programs in four separate sectors (i.e., technical, economic-administrative, services and health, and agricultural), and they may choose between a full-time school-based education and a practicebased apprenticeship system. The best students can move on to higher vocational education and even finish with a university degree. The other $40 \%$ of students enter general secondary education after primary school and choose between a track leading to higher vocational and/or pre-university education. The vocational track has less status than the general track and especially in pre-vocational education; children from disadvantaged groups (i.e., traditional working class and minority groups) are over-represented in this group. Although these students have a formal opportunity to enter higher vocational education and even university, only $15 \%$ do so (Central Bureau of Statistics, 2009). For most children who enter pre-vocational education, formal education ends at age 17 (when compulsory education ends) or 18 (after finishing secondary vocational education).
} 
( 1 = strongly agree, $5=$ strongly disagree $)$. The scales demonstrated adequate internal consistency (Cronbach's alpha .82 to .84). Career reflection was measured by eleven items, for example: "In order to find out what I really consider important in life, I talk to my parents or caregivers." Career forming was measured by fourteen items, for example: "I do extra things in my training, so that I have more chance at getting interesting/enjoyable work." Networking contained seven items, for example: "I talk to skilled people about my future plans."

\section{Career learning environment}

Methods and instruments for career guidance and the degree to which the curriculum was student-centered en practice-based were taken into account as variables in this study. To identify career methods and instruments, a literature study and interviews with school leaders were conducted. Career-choice tests are frequently used in vocational education as are curriculum methods in the form of written material geared, career talks (one-on-one with each student, only with students who threaten to dropout, or with the whole class) and the engagement of a career counselor. In addition, two innovative instruments in the area of career counseling are presently in use: the Personal Development Plan (PDP) and the Portfolio (PF; Mittendorff, 2010; Mittendorff, Jochems, Meijers, \& Den Brock, 2008). Teachers were asked to complete a questionnaire about which of these methods and instruments are being used. Teachers evaluated the degree to which the curriculum (the program organization) was student-centered and practice-based. By student-centered and practice-based we mean the degree to which students' questions and experiences or concrete occupational experiences determine the actual learning process. Participants responded to the six items used on a 5-point Likert-type scale $(1=$ barely careerorientated, in which course offerings and in-school learning takes a central place, $5=$ a more career-orientated curriculum, in which students have the opportunity to make choices and get practical experience). In addition, students were asked how many internships or work placements they had done. Regarding career-oriented guidance, students were asked questions concerning the degree to which a career dialogue took place at school and in the work place. Six items were used for each of the two scales. A 5-point Likert-type scale was used $(1=$ "Teachers never ask me what I want to learn," 5 = "Teachers ask me very often what I want to learn").

\section{Career identity}

Career identity was defined as the commitment a person has towards specific occupational activities or a specific career. In this study, career identity was operationalized in terms of experienced security with regards to self-knowledge, the current course of study and future work, and the self-confidence derived from this. Career identity was measured with an instrument, consisting of eight items (Cronbach's $\alpha=.81$ ), that was based on studies by Meijers (1995) and Meijers and Wardekker (2002). The response categories of the items vary on a 5-point Likerttype scale $(1=$ strongly agree, $5=$ strongly disagree $)$. An example item is: "My heart is in the work I'm learning to do." 


\section{Learning motivation}

Learning motivation was measured with eight items (Cronbach's $\alpha=.79$ ), based on the contribution of the students in their course of study. This instrument was developed by De Bruijn et al. (2005). Example items are: "I work hard at this course of study" and "When I have something to do for this course of study, I start on it right away."

\section{Choice quality}

Choice quality is the evaluation by the student of fit between his or her aptitudes and occupational wishes and the learnings tasks (s)he has to perform in school, the work placements (s)he has had and the study (s)he has chosen. Choice quality was operationalized using three questions about the degree to which the learning tasks, work placements, and choice of study (e.g. technical, healthcare, economy, or agriculture) correspond with the aptitudes and wishes of the student.

\section{Personal- and situation-bound factors}

These factors consist of two sets of variables: school-type (PVE, SVE-P and SVE-T) and the type of program in which the students were enrolled. The programs were divided into the following groups: technical studies, economics, agriculture, healthcare, PVE-theoretical, and "other." Personal variables were gender, age, internal locus-of-control and study achievements. Internal locus of control was measured with 3 items (Den Hertog, 1992). Achievements were used as indicators of cognitive abilities based on the assumption that the degree to which individuals develop competencies might be partly dependent upon their cognitive abilities (Van Merriënboer \& De Croock, 2002). Students were asked to respond to the statement: "In the past 3 months, I received only passing grades."

\section{Statistical analyses}

To investigate the extent to which learning and career outcomes are explained by career competencies and a career-oriented learning environment for students in PVE and SVE, we carried out regression analyses. The career identity, learning motivation and fit of choice for learning tasks, internship and type of study were used as dependent variables and the variables describing career competencies and the learning environment were used as independent variables. Individual- and situational-characteristics (i.e., gender, age, locus of control, study results, and school-type and program-type) were included as potential confounders.

Due to the hierarchical nature of the data (students within classes within schools), we conducted multi-level regression using the MLWIN v.2.0 program (Rasbash, Charlton, Browne, Healy, \& Cameron, 2005). Explained variance, as not uniquely defined in a multi-level regression model. This is caused by the fact that variance is explained on several levels in the data. Explained variance in a multi-level regression model is not uniquely defined. Indeed, explained variance of one level is 
confounded with explained variance on another level (Hox, 2002; Snijder \& Bosker, 1999). Therefore, because we had to use a multi-level method due to the nature of our data, we calculated the significance of improvement of different models per output variable; we first added career competencies to the basic model and, we secondly added the learning environment variables to career competencies as well as the potential confounders.

\section{Results}

The original instrument assessing career competences among employees distinguished six factors relevant for career development. One of these factors is the ability for career development. The other five factors concern behaviour and motivation regarding career development: reflection on capacities, reflection on motives, work exploration, career control and networking (Kuijpers \& Scheerens, 2006, pp. 316-317). We decided to focus on behaviour and motivation, because it is the more overt and distinguishable characteristic. A subsequent questionnaire-based study with students from Dutch (pre)vocational education was done which included the five behavioural and motivational factors. A confirmatory factor analysis showed that a five-factor model failed to obtain admissible results. This model was therefore eliminated from further consideration. A three-factor model of career competencies fit adequately the data, $\left(\chi^{2}(428)=7869.28, p<.01\right.$; RMSEA $=.06$; CFI $=.83$; TLI $=.81)$. The analysis showed that no significant distinction could be made between reflection on capacities and reflection on motives, nor between work exploration and career control. As a result, the following three career competencies for students were identified: (1) career reflection, reflective behaviour based on experiences and choices to reveal qualities and motives that are important for the future; (2) career shaping, proactive behaviour that influences the course of one's career by researching jobs, making deliberate decisions and taking action to make sure jobs and study choices match one's personal qualities and motives; and (3) networking, interactive behaviour to build and maintain contacts on the internal and external job market, aimed at career development.

Student characteristics, characteristics of their school, characteristics of their learning environment with the Cronbach's alpha of the multi-item scales are displayed in Table 1. The structure of the research group concerning personal and situational variables is given in numbers and percentages. The methods used and the program organization is assessed by the students' instructor. Not all of the instructors completed a questionnaire, which explains the missing data on these variables. All scales had an adequate Cronbach's alpha (i.e., >.70), with the exception of the threeitem Locus of Control Scale, which only had an alpha equal to .62. In the last columns the means and standard deviation of the variables are displayed.

To provide some convergent and discriminant validity evidence, a correlation table of the career related input, throughput and output variables is presented in Table 2. The career competencies are most strongly related, which is to be expected because these competencies are part of a second order latent variable, namely career learning. Although the career competencies correlate, we see that the items within 
Table 1 Career competencies, learning environment, personal and situational characteristics, and outcome variables $(n=3499)$

\begin{tabular}{|c|c|c|c|c|c|c|c|}
\hline $\begin{array}{l}\text { Learning environment } \\
\text { characteristics }\end{array}$ & $N$ & $\%$ & $\begin{array}{l}\% \\
\text { missing }\end{array}$ & $\begin{array}{l}\text { Cronbach's } \\
\text { alpha }\end{array}$ & $\begin{array}{l}\text { Number } \\
\text { items }\end{array}$ & Mean & SD \\
\hline \multicolumn{8}{|l|}{ Methods used ${ }^{\mathrm{a}}$} \\
\hline Test & 225 & 6.43 & 13.11 & - & - & & \\
\hline Career method & 542 & 15.49 & 13.11 & - & - & & \\
\hline Class discussion & 325 & 9.28 & 13.11 & - & - & & \\
\hline Problem discussion & 792 & 22.64 & 13.11 & - & - & & \\
\hline Individual discussion & 1127 & 32.21 & 13.11 & - & - & & \\
\hline Student counselor & 1780 & 50.87 & .80 & - & - & & \\
\hline Project $^{\mathrm{a}}$ & 177 & 5.06 & 11.03 & - & - & & \\
\hline $\mathrm{PF}^{\mathrm{a}}$ & 1326 & 37.93 & 11.46 & - & - & & \\
\hline $\mathrm{PDP}^{\mathrm{a}}$ & 718 & 20.52 & 11.46 & - & - & & \\
\hline Program organization $^{\mathrm{a}}$ & & & 11.03 & .76 & 6 & 2.50 & .76 \\
\hline Internships & & & .00 & - & - & 1.80 & 1.12 \\
\hline Career dialogue at School & & & .66 & .83 & 6 & 2.58 & .79 \\
\hline Career dialogue on the job & & & 6.34 & .88 & 6 & 3.49 & .82 \\
\hline \multicolumn{8}{|l|}{ Student characteristics } \\
\hline Gender Male & 1931 & 55.18 & 2.92 & - & - & & \\
\hline Ethnicity Non-Dutch & 376 & 10.74 & 5.40 & - & - & & \\
\hline Age & & & 7.80 & - & - & 18.51 & 4.70 \\
\hline Internal locus of control & & & .06 & .62 & 3 & 2.16 & 1.28 \\
\hline Learning achievement & & & 1.11 & - & - & 3.18 & 1.26 \\
\hline \multicolumn{8}{|l|}{ Situational characteristics } \\
\hline \multicolumn{8}{|l|}{ School type } \\
\hline PVE & 1280 & 36.58 & .00 & - & & & \\
\hline SVE-P & 489 & 13.97 & .00 & - & & & \\
\hline SVE-T & 1697 & 48.50 & .00 & - & & & \\
\hline Other/unknown & 33 & 0.09 & .00 & & & & \\
\hline \multicolumn{8}{|l|}{ Specialization } \\
\hline Technical & 530 & 15.15 & .00 & - & - & & \\
\hline Healthcare & 1040 & 29.72 & .00 & - & - & & \\
\hline Economy & 595 & 17.00 & .00 & - & - & & \\
\hline Agriculture & 314 & 8.97 & .00 & - & - & & \\
\hline PVE-theoretical & 495 & 14.15 & .00 & - & - & & \\
\hline Rest & 525 & 15.00 & .00 & - & - & & \\
\hline \multicolumn{8}{|l|}{ Career competencies } \\
\hline Career reflection & & & 1.01 & .82 & 11 & 3.35 & .56 \\
\hline Career forming & & & .01 & .84 & 14 & 3.01 & .55 \\
\hline Career networking & & & .37 & .82 & 7 & 3.05 & .69 \\
\hline \multicolumn{8}{|l|}{ Outcome measures } \\
\hline Career identity & & & .83 & .81 & 8 & 3.36 & .70 \\
\hline Learning motivation & & & .01 & .79 & 8 & 3.31 & .63 \\
\hline
\end{tabular}


Table 1 continued

\begin{tabular}{|c|c|c|c|c|c|c|}
\hline $\begin{array}{l}\text { Learning environment } \\
\text { characteristics }\end{array}$ & $N$ & $\begin{array}{l}\% \\
\text { missing }\end{array}$ & $\begin{array}{l}\text { Cronbach's } \\
\text { alpha }\end{array}$ & $\begin{array}{l}\text { Number } \\
\text { items }\end{array}$ & Mean & SD \\
\hline Fit of choice for learning tasks & & .94 & - & - & 2.93 & 1.05 \\
\hline Fit of choice for internship & & 2.60 & - & - & 3.28 & 1.17 \\
\hline Fit of choice for School direction & & .51 & - & - & 3.61 & 1.01 \\
\hline
\end{tabular}

${ }^{\text {a }}$ Measured by instructor

Table 2 Correlations between input, throughput and output variables

\begin{tabular}{|c|c|c|c|c|c|c|c|c|c|c|c|}
\hline & 1 & 2 & 3 & 4 & 5 & 6 & 7 & 8 & 9 & 10 & 11 \\
\hline $\begin{array}{l}\text { 1. Program } \\
\text { organization }\end{array}$ & 1.00 & & & & & & & & & & \\
\hline $\begin{array}{l}\text { 2. Career } \\
\text { dialogue at } \\
\text { School }\end{array}$ & $.18^{*}$ & 1.00 & & & & & & & & & \\
\hline $\begin{array}{l}\text { 3. Career } \\
\text { dialogue on } \\
\text { the job }\end{array}$ & $.09 *$ & $.24 *$ & $1.00 *$ & & & & & & & & \\
\hline $\begin{array}{l}\text { 4. Career } \\
\text { reflection }\end{array}$ & $.10^{*}$ & $.20^{*}$ & $.28 *$ & 1.00 & & & & & & & \\
\hline $\begin{array}{l}\text { 5. Career } \\
\text { forming }\end{array}$ & $.09 *$ & $.35^{*}$ & $.24 *$ & $.59 *$ & 1.00 & & & & & & \\
\hline $\begin{array}{l}\text { 6. Career } \\
\text { networking }\end{array}$ & $.05^{*}$ & $.24 *$ & $.28 *$ & $.61 *$ & $.68 *$ & 1.00 & & & & & \\
\hline $\begin{array}{l}\text { 7. Career } \\
\text { identity }\end{array}$ & $.08^{*}$ & $.23^{*}$ & $.24 *$ & $.24 *$ & $.38 *$ & $.31 *$ & 1.00 & & & & \\
\hline $\begin{array}{l}\text { 8. Learning } \\
\text { motivation }\end{array}$ & .03 & $.23^{*}$ & $.13^{*}$ & $.16^{*}$ & $.26^{*}$ & $.13^{*}$ & $.44 *$ & 1.00 & & & \\
\hline $\begin{array}{l}\text { 9. Fit of choice } \\
\text { for learning } \\
\text { tasks }\end{array}$ & $.08^{*}$ & $.18^{*}$ & $.20 *$ & $.14 *$ & $.23 *$ & $.17 *$ & $.58 *$ & $.37 *$ & 1.00 & & \\
\hline $\begin{array}{l}\text { 10. Fit of } \\
\text { choice for } \\
\text { internship }\end{array}$ & $.10^{*}$ & $.25^{*}$ & $.13^{*}$ & $.17 *$ & $.26^{*}$ & $.17 *$ & $.27 *$ & $.21^{*}$ & $.26^{*}$ & 1.00 & \\
\hline $\begin{array}{l}\text { 11. Fit of } \\
\text { choice for } \\
\text { school } \\
\text { direction }\end{array}$ & $.07 *$ & $.13^{*}$ & $.23 *$ & $.14 *$ & $.21^{*}$ & $.19 *$ & $.27 *$ & $.12^{*}$ & $.2 * *$ & $.35^{*}$ & 1.00 \\
\hline
\end{tabular}

$* p<.01$ (two-tailed)

the variables (Cronbach's alpha) correlate more strongly than between the variables. This indicates discriminant validity; therefore, we can assume that the variables used in the study measure different concepts. 
The regression coefficients and standards errors for the multi-level regressions for each of the independent variables are shown in Table 3. This table shows the $z$-scores and the standard errors of the independent variables. The independent variables contribute significantly to (or explain) the scores of the dependent variable with a $p$ value of .05 , if the standard error (explained between parentheses) times 1.96 is lower than the $z$-score. The percentage of explained variance for the dependent variables varies between $24 \%$ (fit of choice of learning tasks) and $41 \%$ (fit of study choice), which may be characterized as having a medium to large effect size (Cohen, 1988). The amount of variance due to differences between schools is negligible, being only about $1 \%$ of the total variance, even though it is statistically significant. The amount of variance due to differences between classes is also statistically significant, varying between 4 and $10 \%$, which reflects a small-medium effect size (Cohen, 1988).

The results showed that career competencies explain the variance on the scores of career identity, learning motivation and fit of choice of learning tasks. Career forming is significantly related to these three outcomes, with moderate effect sizes. Students who judge their career behavior as pro-active (career forming) appear to have-based on knowledge about themselves and work-confidence in their future career (career identity). They are committed to their current study (learning motivation) and chose learning tasks that match their capacities and motivation (fit of choice of learning tasks). Networking proves to contribute to scores on career identity, however, networking is negatively related to learning motivation. Career identity proves to explain a substantial portion of the variance of scores relating to learning motivation and the fit of choices that students make. Students who have a career identity (i.e. are self-confident with respect to their future career), feel more committed to their studies and say that they make choices of learning tasks, internship and of type of study that match their capacities and motivation.

The results showed that different aspects of the learning environment explain the variance between career outcome scores. Especially the career dialogue at school and in the workplace (the work placement) contributed to most of the criterion variables. Therefore, conversations with the students held at school about their aptitudes, motives and future career, explain the variance of career identity, learning motivation, and suitable choices of learning tasks and type of study. Talking with the students at the work place relates to the development of a career identity and to experienced better choices of work placement and study. Also a curriculum that is practice and inquiry based (program organization) explains the experienced fit of choice of learning tasks and study. Students who have more experience with work placements are students who experience a better fit between their aptitudes and the work placements.

Contrary to what one would expect, the results show a negative relationship between tests and career identity, and between career methods and learning motivation. There is no evidence that career tests and methods contributed to suitable choices. Also instruments, such as the portfolio (PF) and personal development plan (PDP) seem to have no impact on career outcomes. Moreover, the form of conversation (i.e. whether it is a discussion in the classroom, a discussion 
Table 3 Results of multilevel regression analyses with career identity, learning motivation and fit of choice as dependent variables

\begin{tabular}{|c|c|c|c|c|c|}
\hline & $\begin{array}{l}\text { Career } \\
\text { identity }\end{array}$ & $\begin{array}{l}\text { Learning } \\
\text { motivation }\end{array}$ & $\begin{array}{l}\text { Fit of choice } \\
\text { for learning } \\
\text { tasks }\end{array}$ & $\begin{array}{l}\text { Fit of choice } \\
\text { for internship }\end{array}$ & $\begin{array}{l}\text { Fit of choice } \\
\text { for school } \\
\text { direction }\end{array}$ \\
\hline Career identity & & $.33(.02)^{*}$ & $.15(.02)^{*}$ & $.19(.02)^{*}$ & $.56(.02)^{*}$ \\
\hline \multicolumn{6}{|l|}{ Career competencies } \\
\hline Career reflection & $.10(.02)^{*}$ & $-.01(.02)$ & $.02(.03)$ & $.03(.03)$ & $-.02(.02)$ \\
\hline Career forming & $.24(.03)^{*}$ & $.15(.03)^{*}$ & $.13(.03)^{*}$ & $.05(.03)$ & $.03(.03)$ \\
\hline Networking & $.10(.03)^{*}$ & $-.10(.02)^{*}$ & $.00(.03)$ & $.02(.03)$ & $-.02(.02)$ \\
\hline \multicolumn{6}{|l|}{ Method (w.r.t. none) $)^{a, b}$} \\
\hline Test & $-.26(.11)^{*}$ & $.16(.13)$ & $.10(.13)$ & $-.03(14)$ & $-.01(.08)$ \\
\hline Career method & $.08(.12)$ & $-.31(.14)^{*}$ & $.16(.14)$ & $.17(.16)$ & $-.06(.08)$ \\
\hline Class discussion & $.05(.18)$ & $-.23(.14)$ & $.18(.13)$ & $.11(.15)$ & $-.09(.08)$ \\
\hline Problem discussion & $.12(.10)$ & $-.25(.12)^{*}$ & $.23(.12)$ & $.08(.14)$ & $-.13(.07)$ \\
\hline Individual discussion & $.04(.10)$ & $-.24(.12)^{*}$ & $.14(.12)$ & $-.02(.14)$ & $-.15(.07)^{*}$ \\
\hline 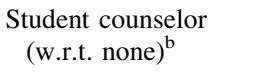 & $-.03(.04)$ & $.06(.04)$ & $.04(.04)$ & $.00(.04)$ & $-.01(.03)$ \\
\hline Project (w.r.t. none) ${ }^{\mathrm{a}, \mathrm{b}}$ & $-.02(.15)$ & $-.17(.17)$ & $-.33(.18)$ & $-.05(.21)$ & $-.17(.11)$ \\
\hline \multicolumn{6}{|c|}{ Instruments (w.r.t. none) ${ }^{\mathrm{a}, \mathrm{b}}$} \\
\hline $\mathrm{PF}$ & $.03(.06)$ & $-.01(.01)$ & $-.12(.07)$ & $-.09(.08)$ & $.02(.05)$ \\
\hline PDP & $-.02(.09)$ & $-.08(.10)$ & $.14(.10)$ & $-.01(.12)$ & $.05(.06)$ \\
\hline Program organization $^{\mathrm{a}}$ & $.01(.03)$ & $.05(.04)$ & $.08(.04)^{*}$ & $.07(.04)$ & $.05(.02)^{*}$ \\
\hline Internships & $.02(.02)$ & $.01(.02)$ & $-.00(02)$ & $.08(.02)^{*}$ & $.02(.02)$ \\
\hline \multicolumn{6}{|l|}{ Career dialogue } \\
\hline School & $.07(.02)^{*}$ & $.10(.02)^{*}$ & $.13(.02)^{*}$ & $-.01(.02)$ & $.04(.02)^{*}$ \\
\hline Practice & $.13(.02)^{*}$ & $.03(.02)$ & $.02(.02)$ & $.15(.02)^{*}$ & $.06(.02)^{*}$ \\
\hline $\begin{array}{l}\text { Gender (boy w.r.t. } \\
\text { girl) }^{\mathrm{b}}\end{array}$ & $.06(.05)$ & $-.40(.05)^{*}$ & $-.05(.05)$ & $-.11(.05)^{*}$ & $-.11(.04)^{*}$ \\
\hline Age & $.07(.03)^{*}$ & $.04(.03)$ & $-.04(.03)$ & $-.10(.03)^{*}$ & $-.03(.02)$ \\
\hline $\begin{array}{l}\text { Ethnicity (non-Dutch } \\
\text { w.r.t. Dutch }\end{array}$ & $.10(.06)$ & $.26(.06)^{*}$ & $-.10(.07)$ & $-.24(.06)^{*}$ & $-.11(.06)$ \\
\hline $\begin{array}{l}\text { Internal locus of } \\
\text { control }\end{array}$ & $.14(.02)^{*}$ & $.08(.02)^{*}$ & $.04(.02)$ & $.01(.02)$ & $.00(.02)$ \\
\hline Learning achievement & $.12(.02)^{*}$ & $.06(.02)^{*}$ & $.05(.02)^{*}$ & $.01(.02)$ & $.04(.02)^{*}$ \\
\hline SVE-P (w.r.t. PVE) ${ }^{\mathrm{b}}$ & $-.03(.11)$ & $-.40(.12)^{*}$ & $-.07(.13)$ & $.27(.14)$ & $-.03(.09)$ \\
\hline SVE-T (w.r.t. PVE) ${ }^{b}$ & $-.24(.08)^{*}$ & $-.34(.09)^{*}$ & $.01(.09)$ & $.28(.11)^{*}$ & $.01(.06)$ \\
\hline $\begin{array}{l}\text { Technical (w.r.t. } \\
\text { "rest") }\end{array}$ & $-.04(.09)$ & $.32(.10)^{*}$ & $-.26(.10)^{*}$ & $-.19(.12)$ & $-.09(.06)$ \\
\hline $\begin{array}{l}\text { Health care (w.r.t. } \\
\text { "rest") }\end{array}$ & $.12(.08)$ & $-.02(.09)$ & $-.25(.09)^{*}$ & $-.41(.11)^{*}$ & $-.12(.06)^{*}$ \\
\hline $\begin{array}{l}\text { Economics (w.r.t. } \\
\text { "rest") }\end{array}$ & $-.28(.08)^{*}$ & $.07(.10)$ & $-.20(10)$ & $-.13(.12)$ & $-.24(.01)^{*}$ \\
\hline $\begin{array}{l}\text { Agriculture (w.r.t. } \\
\text { "rest") }\end{array}$ & $.05(.12)$ & $.04(.15)$ & $-.05(.15)$ & $.19(.17)$ & $-.04(.11)$ \\
\hline School variance & $.00(.00)$ & $.01(.01)$ & $.01(.01)$ & $.01(.01)$ & $.01(.00)$ \\
\hline
\end{tabular}


Table 3 continued

\begin{tabular}{|c|c|c|c|c|c|}
\hline & $\begin{array}{l}\text { Career } \\
\text { identity }\end{array}$ & $\begin{array}{l}\text { Learning } \\
\text { motivation }\end{array}$ & $\begin{array}{l}\text { Fit of choice } \\
\text { for learning } \\
\text { tasks }\end{array}$ & $\begin{array}{l}\text { Fit of choice } \\
\text { for internship }\end{array}$ & $\begin{array}{l}\text { Fit of choice } \\
\text { for school } \\
\text { direction }\end{array}$ \\
\hline Class variance & $.04(.01)^{*}$ & $.07(.02)^{*}$ & $.06(.02)^{*}$ & $.10(.02)^{*}$ & $.00(.00)$ \\
\hline Student variance & $.70(.02)^{*}$ & $.65(.02)^{*}$ & $.76(.02)^{*}$ & $.72(.02)^{*}$ & $.59(.02)^{*}$ \\
\hline $\begin{array}{l}\text { Total explained } \\
\text { variance }(\%)\end{array}$ & 31 & 35 & 24 & 29 & 41 \\
\hline $\begin{array}{l}\text { Model improvement } \\
\text { through addition } \\
\text { career competencies }\end{array}$ & $540 *(\mathrm{df} 3)$ & $293 *($ df 3$)$ & $299 *($ df 3$)$ & $249 *(\mathrm{df} 3)$ & $269 *($ df 3$)$ \\
\hline $\begin{array}{l}\text { Model improvement } \\
\text { through addition } \\
\text { learning } \\
\text { environment to } \\
\text { personal, situational } \\
\text { and career } \\
\text { competencies } \\
\text { variables }\end{array}$ & $1122 *(\mathrm{df} 13)$ & $962 *($ df 13$)$ & $1638 *(\mathrm{df} 13)$ & $1675^{*}(\mathrm{df} 13)$ & $1652 *(\mathrm{df} 13)$ \\
\hline
\end{tabular}

Note $N=2424,2424,2407,2382$ and 2411, respectively. All continuous variables were transformed to $z$-scores. Regression coefficients are shown, with the standard errors between parentheses

$* p<.05$

a Evaluated by the instructor

b Categorical variable

about school problems or an individual discussion), did not seem to contribute to the criterion variables. Conversations about problems and individual conversations are even negatively related to learning motivation. Individual conversations are also negatively related to school direction choice. Considering the results, it seems that the form of the conversation, as well as the role of the person who leads it, and the presence of a student counselor, did not significantly contribute positively to learning and career outcomes. However, the content of the conversation, namely the career, did contribute to the scores on the outcomes. Career dialogues-either in school or on the job-are significantly beneficial for most of the variables, with small-moderate effect sizes.

Looking at the results per criterion variable, we see that career identity was positively related to career competencies and career dialogue. Learning motivation was mainly related to career identity, career forming, and the career dialogue at school. The fit or choice of learning tasks was explained by career identity development, networking, a practice and inquiry-based curriculum and the career dialogue at school. The fit of choice for work placement was explained by experience in previous placements and talking on the job about the career. The fit of study choice could be explained by the degree to which the curriculum was practice and inquiry based and again by the career dialogue, at school as well as in the internship. 
Students in the SVE schools have significantly smaller means with respect to those in PVE on learning motivation. Moreover, students from the theoretical track of SVE schools have lower means on career identity, but experience a better choice fit on internship than PVE students. We see that students with a technical specialization score lower on choice fit with respect to learning tasks but higher on learning motivation than the "other" students. Students in health care experienced less choice fit with respect to learning tasks, internship and study direction. Students studying economics showed a weaker career identity and find their internship and study less suitable for themselves. Students in agriculture find the fit of choice of internship better than students in the "rest category."

With regard to personal factors, higher scores on learning achievement were positively related to all outcome measures, except for the fit of choice of work placement. Higher scores on internal locus of control was positively related to career identity and learning motivation. Non-Dutch students appeared to experience more learning motivation but less fit of choice of work placement than Dutch students. Older students had a stronger career identity but experience less fit of choice of internship than younger students, and girls were more motivated for learning and experience a better fit of choice of work placement and study than boys.

To examine the specific contribution of input and throughput career variables as a set to the output variables, we added career competencies to the basic-model. Secondly, we added the learning environment variables to career competencies as well as the personal and situational variables. The $\chi^{2}$ values and degrees of freedom are displayed in Table 3. For all output variables, the model was significantly improved by adding the career competencies to the basic-model $(p<.001)$. In adding the career competencies as well as personal and situational variables, the learning environment variables proved to contribute significantly to all output variables. The change in the model adding the learning environment variables was significant $(p<.001)$. So we see that the learning environment makes a difference in students' commitment towards specific occupational activities or a specific career, in learning motivation and in fit of career choices they make.

\section{Discussion}

Policy makers as well as school managers believe that intensive career education and guidance, that enables students to develop career competencies, will result in more intrinsically motivated students because it will help students develop a career identity. They expect that a well-developed career identity, in turn, will result in educational choices and choices for work placements that fit better with personal aptitudes and wishes. In this article, we have investigated if these relationships indeed exist.

The question as to whether career competencies are related to career identity was answered affirmatively in this study. Career forming and networking were positively related and career reflection was negatively related. The negative relationship between career reflection and career identity could be explained by the argument 
that students, who have not developed a career identity yet, are more likely to reflect on their aptitudes and motives. Moreover, career forming explained the scores on the variables learning motivation and the quality or fit in learning tasks in relation to personal aptitudes and wishes. Also career identity related to these variables and to the experienced quality or fit in study choice and work placement. Career interventions in schools aiming at the development and actual use of career competencies had positive effects that go beyond well-known effects like the development of career decision-making skills and career knowledge.

Our findings suggested that to compensate for the results of personal factors on career outcomes, aspects of the career learning environment with similar effect sizes, might be implemented. For example, older students had a stronger career identity. To compensate for this gap among younger students, the latter may need to have more career dialogues at school and in practice. Also, boys, younger students, and non-Dutch students chose work placements that did not match as well as the other groups. Offering them more placements and/or career conversations in their internships might compensate for this. Students with a lower internal locus of control and lower learning achievements might need more career dialogues at school to compensate for their personal attributes in career identity and learning motivation.

The results suggested that a traditional career approach that is characterized by an absence of dialogue (Kuijpers et al., 2011) did not prove to contribute to career identity, learning motivation, or experienced fit between aptitudes and choices for work placements and study. A career dialogue at school and in the workplace (i.e., the work placement), however, contributed to career identity development, learning motivation, and experienced quality of choices. The form of the conversation, the role of the person who leads it, and the presence of a student counselor did not contribute positively to learning and career outcomes. The content of the conversation, however, did contribute to positive outcomes. These results were in line with Masdonati, Massoudi, and Rossier's (2009) research results, in which faceto-face career counselling can be considered to be a very effective intervention method. More specifically, they found that the quality of the working alliance between counsellor and client plays an important role in the effectiveness of career counselling. They suggested that face-to-face counselling should not be considered only a cognitively-oriented intervention. Our results supported this suggestion: a dialogue about the personal meaning of real-life experiences with work-in which emotions are not neglected-contributes positively to the quality of the working alliance, whereby a working alliance is understood as the result of a combination of an agreement between counsellor and student about the goals of the counselling, an agreement about how to reach these goals, and the development of a personal bond between them.

The research results were also in line with Savickas's (2002, 2005) career construction theory. Savickas purported that individuals generate their own career life themes in career conversations. According to McIlveen and Patton (2007), however, in its current form his theory does not offer a psychological explanation for how individuals enact a process of self-construction via "storying." Our results suggested that this process is facilitated by real life experiences in work placements; 
the more experiences with "real work" students have, the more fruitful a career dialogue proves to be. Several researchers, however, showed that teachers find it very difficult to start a dialogue with their students about concrete experiences in work placements (Winters, Meijers, Kuijpers, \& Baert, 2009; Winters, Meijers, Lengelle, \& Baert, 2012; Winters et al., in press). The culture of schools and thus of conversations between teachers and students is still very monological; this is largely due to the fact that the transmission of undisputed knowledge is the pivot around which everything turns (Gatto, 2009). The realization of a strong career learning environment, therefore, depends, to a large extent, on the possibilities teachers get to develop a new career identity (Meijers \& Lengelle, 2012).

This study had at least two limitations. First, although we wanted to measure actual career behavior in contrast to decision-making skills, attitudes or knowledge, using a self-report method made it virtually impossible to separate actual career behavior from attitudes, because participants have to appraise their behavior in order to rate the items. The career competencies used in this study included career reflection and exploration, which are closely related to decision-making skills. Although the way we measured career competencies is a step away from a completely cognitive approach, we must admit that there are boundaries between skills, attitudes, and knowledge and actual career behavior. To measure actual career behavior, a behavioral approach utilizing outside observers would be necessary.

A second limitation of this study is that no strong evidence for effectiveness can be presented due to the cross sectional design with no control group. Moreover, the lack of well-validated instruments limited the value of the results. However, the explained variance of the criterion variables did indicate that there were relationships between career competencies and career learning environment on the one hand, and career identity, learning motivation and the experienced quality of choices on the other. To be more certain of the nature and extent of these relationships, more research using well-validated measurement instruments should be conducted concerning the impact of vocational training in large representative samples. Additionally, more complex conceptual models must be developed.

\section{References}

Arthur, M. B., Inkson, K., \& Pringle, J. (1999). The new careers: Individual action and economic change. London, UK: Sage.

Arthur, M. B., Khapova, S. N., \& Wilderom, C. P. M. (2005). Career success in a boundaryless career world. Journal of Organizational Behaviour, 26, 177-202. doi:10.1002/job.290.

Bailey, T. R., Hughes, K. L., \& Moore, D. T. (2004). Working knowledge: Work-based learning and education reform. New York, NY: Routledge Farmer.

Beck, U. (1994). The reinvention of politics: Towards a theory of reflexive modernisation. In U. Beck, A. Giddens, \& S. Lash (Eds.), Reflexive modernisation (pp. 1-56). Cambridge, UK: Polity Press.

Bimrose, J., Barnes, S.-A., Hughes, D., \& Orton, M. (2004). What is effective guidance? Evidence from longitudinal case studies in England. Coventry, UK: Warwick Institute for Employment Research/ University of Warwick.

Bruner, J. (1990). Acts of meaning. Cambridge, MA: Harvard University Press. 
Central Bureau of Statistics. (2009). Statistisch Jaarboek 2009 [Statistical Year Book 2009]. Den Haag/ Heerlen, The Netherlands: Author.

Cohen, J. (1988). Statistical power analysis for the behavioral sciences (2nd ed.). Hillsdale, NJ: Lawrence Erlbaum.

Company, F. J. (2009). Vocational guidance and career counselling in the European Union: Origins and recent trends. In R. Maclean \& D. N. Wilson (Eds.), International handbook of education for the changing world of work: Bridging academic and vocational learning (pp. 2313-2329). New York, NY: Springer.

Dawis, R. V. (1996). Vocational psychology, vocational adjustment, and the workforce: Some familiar and unanticipated consequences. Psychology, Public Policy, and Law, 2, 229-248. doi: 10.1037//1076-8971.2.2.229.

De Bruijn, E., Overmaat, M., Glaudé, M., Heemskerk, I., Leeman, Y., Roeleveld, J., et al. (2005). Krachtige leeromgevingen in het middelbaar beroepsonderwijs: vormgeving en effecten [Strong learning environments in secondary vocational education: Design and effects]. Pedagogische Studiën, 82, 77-95.

Den Hertog, P. C. (1992). De "IE-18 locus of control"-vragenlijst: Betrouwbaarheid en validiteit van een gewijzigde versie [The "IE-18 locus of control" questionnaire: Reliability and validity of a changed version]. Nederlands Tijdschrift voor de Psychologie, 47, 82-87.

Dieleman, A., \& Meijers, F. (2005). Paradise lost: Youth in transition in The Netherlands. In N. Bagnall (Ed.), Youth transition in a globalised marketplace (pp. 75-99). New York, NY: Nova Science.

Eurostat. (2008). Europe in figures. Eurostat yearbook 2008. Luxembourg, Luxembourg: Office for Official Publications of the European Communities.

Frijda, N. (1989). The emotions. Cambridge, UK: Cambridge University Press.

Gatto, J. T. (2009). Weapons of mass instruction: A school teacher's journey through the dark world of compulsory schooling. Gabriola Island, Canada: New Society.

Geurts, J., \& Meijers, F. (2009). Vocational education in The Netherlands: In search of a new identity. In R. Maclean \& D. N. Wilson (Eds.), International handbook of education for the changing world of work: Bridging academic and vocational learning (pp. 483-499). New York, NY: Springer.

Giddens, A. (1991). Modernity and self-identity: The self and society in the late modern age. London, UK: Polity Press.

Guindon, M. H., \& Hanna, F. J. (2002). Coincidence, happenstance, serendipity, fate, or the hand of God: Case studies in synchronicity. The Career Development Quarterly, 50, 195-208.

Gysbers, N. C., \& Henderson, P. (2005). Designing, implementing, and managing a comprehensive school guidance and counseling program. In C. A. Sink (Ed.), Contemporary school counseling: Theory, research, and practice (pp. 151-188). Boston, MA: Houghton Mifflin.

Hochschild, A. (1983). The managed heart: Commercialisation of human feelings. Berkeley, CA: University of California Press.

Holt, J. (1995). How children fail (Rev ed.). Reading, MA: Perseus Books.

Hox, J. (2002). Multilevel analysis: Techniques and applications. New York, NY: Lawrence Erlbaum.

Hughes, D., Bosley, S., Bowes, L., \& Bysshe, S. (2002). The economic benefits and guidance [Research report]. Derby, UK: Centre for Guidance Studies, University of Derby.

Hughes, K. L., \& Karp, M. M. (2004). School-based career development: A synthesis of the literature. New York, NY: Columbia University-Institute on Education and the Economy Teachers College.

Irving, B. A., \& Malik, B. (Eds.). (2005). Critical reflections on career education and guidance: Promoting social justice within a global economy. London, UK: Routledge Farmer.

Jarvis, P., \& Keeley, E. S. (2003). From vocational decision making to career building: Blueprint, real games, and school counseling. Professional School Counseling, 6, 244-251.

Killeen, J. (1996). The learning and economic outcomes of guidance. In A. G. Watts, B. Law, J. Killeen, J. M. Kidd, \& R. Hawthorn (Eds.), Rethinking careers education and guidance: Theory, policy and practice (pp. 72-94). London, UK: Routledge.

Killeen, J., Edwards, A., Barnes, A., \& Watts, A. G. (1999). Evaluating the UK national pilot of The Real Game: Technical report on the quantitative analysis of learning outcomes [NICEC project report]. Cambridge, UK: Careers Research and Advisory Centre.

Killeen, J., White, M., \& Watts, A. G. (1992). The economic value of careers guidance. London, UK: Policy Studies Institute/Department for Education and Employment.

Krieshok, T. S., Black, M. D., \& McKay, R. A. (2009). Career decision making: The limits of rationality and the abundance of non-conscious processes. Journal of Vocational Behavior, 76, 275-290. doi: 10.1016/j.jvb.2009.04.006. 
Krumboltz, J. D., \& Worthington, R. L. (1999). The school-to-work transition from a learning theory perspective. The Career Development Quarterly, 47, 312-325.

Kuijpers, M., Meijers, F., \& Gundy, C. (2011). The relationship between learning environment and career competencies of students in vocational education. Journal of Vocational Behavior, 78, 21-30. doi: 10.1016/j.jvb.2010.05.005.

Kuijpers, M. A. C. T., \& Scheerens, J. (2006). Career competencies for the modern career. Journal of Career Development, 32, 303-319.

Kuijpers, M., Schyns, B., \& Scheerens, J. (2006). Career competencies for career success. The Career Development Quarterly, 55, 168-179. doi:10.1177/0894845305283006.

Light, R. (2001). Making the most of college. Students speak their minds. Cambridge, MA: Harvard University Press.

Masdonati, J., Massoudi, K., \& Rossier, J. (2009). Effectiveness of career counseling and the impact of the working alliance. Journal of Career Development, 36, 183-203. doi:10.1177/0894845309340798.

McIlveen, P., \& Patton, W. (2007). Dialogical self: Author and narrator of career life themes. International Journal of Educational and Vocational Guidance, 7, 67-80.

McWhirter, E. H., Rasheed, S., \& Crothers, M. (2000). The effects of high school career education on socialcognitive variables. Journal of Counseling Psychology, 47, 330-341. doi:10.1037/0022-0167.47.3.330.

Meijers, F. (1995). Arbeidsidentiteit:Sstudie- en beroepskeuze in de post-industrièle samenleving. [Career identity: Study and career choices in a post-industrial society] Alphen a/d Rijn, The Netherlands: Samsom H. D. Tjeenk Willink.

Meijers, F. (2008). Mentoring in Dutch vocational education: An unfulfilled promise. British Journal of Guidance and Counselling, 36, 235-252. doi:10.1080/03069880802090008.

Meijers, F., \& Lengelle, R. (2012). Narratives at work: The development of career identity. British Journal of Guidance and Counselling, 40, 157-177. doi:10.1080/03069885.2012.665159.

Meijers, F., \& Wardekker, W. (2002). Career learning in a changing world: The role of emotions. International Journal for the Advancement of Counselling, 24(3), 149-167.

Mitchell, K. E., Levin, A. S., \& Krumboltz, J. D. (1999). Planned happenstance: Constructing unexpected career ppportunities. Journal of Counselling and Development, 77, 115-124.

Mittendorff, K. (2010). Career conversations in senior secondary vocational education (Doctoral thesis). Eindhoven, The Netherlands: Eindhoven University of Technology.

Mittendorff, K., Jochems, W., Meijers, F., \& Den Brock, P. (2008). Differences and similarities in the use of the portfolio and personal development plan for career guidance in various vocational schools in The Netherlands. Journal of Vocational Education and Training, 60, 75-91. doi: $10.1080 / 13636820701828903$.

National Center for Education Statistics. (2001). The condition of education 2001. Washington, DC: U.S. Department of Education.

Oliver, L. W., \& Spokane, A. R. (1988). Career-intervention outcomes: What contributes to client gain? Journal of Counseling Psychology, 35, 447-462.

Organisation for Economic Co-operation and Development. (2004). Career guidance and public policy: Bridging the gap. Paris, France: Author.

Parsad, B., Alexander, D., Farris, E., \& Hudson, L. (2003). High school guidance counseling [NCES 2003-015]. Washington, DC: U.S. Department of Education, National Center for Education Statistics.

Prawat, R. S. (1998). Current self-regulation views of learning and motivation viewed through a Deweyan lens: The problems with dualism. American Educational Research Journal, 35, 199-224. doi: $10.2307 / 1163423$.

Rasbash, J., Charlton, C., Browne, W. J., Healy, M., \& Cameron, B. (2005). MLwiN Version 2.02. [Computer software]. Bristol, UK: University of Bristol, Centre for Multilevel Modelling.

Savickas, M. L. (2000). Renovating the psychology of careers for the twenty-first century. In A. Collin \& R. A. Young (Eds.), The future of career (pp. 53-68). Cambridge, UK: Cambridge University Press.

Savickas, M. (2002). Career construction: A developmental theory of vocational behavior. In D. A. Brown (Ed.), Career choice and development (4th ed., pp. 149-205). San Francisco, CA: JosseyBass.

Savickas, M. (2005). The theory and practice of career construction. In S. D. Brown \& R. W. Lent (Eds.), Career development and counseling: Putting theory and research to work (pp. 42-70). Hoboken, NJ: Wiley.

Savickas, M., Van Esbroeck, R., \& Herr, E. L. (2005). The internationalization of educational and vocational guidance. The Career Development Quarterly, 54, 77-85. 
Sennett, R. (1998). The corrosion of character: The personal consequences of work in the new capitalism. London, UK: Norton.

Snijder, T., \& Bosker, R. (1999). Multilevel analysis: An introduction to basic and advanced multilevel modeling. London, UK: Sage.

Tinto, V. (1993). Leaving college: Rethinking the causes and cures of student attrition (2nd ed.). Chicago, IL: The University of Chicago Press.

Tinto, V. (2000). Linking learning and leaving: Exploring the role of college classrooms in student departure. In J. Braxton (Ed.), Reworking the student departure puzzle (pp. 58-74). Nashville, TN: Vanderbilt University Press.

Van Merriënboer, J. J. G., \& De Croock, M. B. M. (2002). Performance-based ISD: 10 steps to complex learning. Performance Improvement, 41(7), 33-38. doi:10.1002/pfi.4140410708.

Van Woerkom, M. (2008). Critical reflection and related higher-level conceptualizations of learning: Realistic or idealistic? Human Resource Development Review, 7, 3-12.

Watts, A. G., \& Sultana, R. G. (2004). Career guidance policies in 37 countries: Contrasts and common themes. International Journal for Educational and Vocational Guidance, 4, 105-122. doi:10.1007/ s10775-005-1025-y.

Whiston, S. C., Sexton, T. L., \& Lasoff, D. L. (1998). Career-intervention outcome: A replication and extension of Oliver and Spokane (1988). Journal of Counseling Psychology, 45, 150-165. doi: 10.1037//0022-0167.45.2.150.

Wijers, G., \& Meijers, F. (1996). Career guidance in the knowledge society. British Journal of Guidance and Counselling, 24, 185-198. doi:10.1080/03069889600760171.

Winters, A., Meijers, F., Harlaar, M., Strik, A., Kuijpers, M., \& Baert, H. (in press). The narrative quality of career conversations in vocational education. Journal of Constructivist Psychology.

Winters, A., Meijers, F., Kuijpers, M., \& Baert, H. (2009). What are vocational training conversations about? Analysis of vocational training conversations in Dutch vocational education from a career learning perspective. Journal of Vocational Education and Training, 61, 247-266. doi:10.1080/ 13636820903194690.

Winters, A., Meijers, F., Lengelle, R., \& Baert, H. (2012). The self in career learning: An evolving dialogue. In H. J. M. Hermans \& T. Gieser (Eds.), Handbook on the dialogical self (pp. 454-469). Cambridge, UK: Cambridge University Press.

Zijlstra, W., \& Meijers, F. (2006). Hoe spannend is het hoger beroepsonderwijs? [How exciting is higher education?] TH\&MA-Tijdschrift voor Hoger Onderwijs en Management, 13, 53-60. 